Ana Dili Eğitimi Dergisi
Journal of Mother Tongue Education
Www.anadiliegitimi.com
Geliş/Received: 01.04 .2021 Kabul/Accepted: 08.06 .2021
Araştırma Makalesi/Research Paper

\title{
Beşinci Sınıf Öğrencilerinin Okuduğunu Anlama, Okuma Motivasyonu ve Türkçe Dersine Yönelik Tutumları Arasındaki ilişki
}

\author{
Tuncay TÜRKBEN* \\ Ceylan GÜNDEĞER**
}

\begin{abstract}
Öz
Bu araştırmanın amacı okuduğunu anlama, okuma motivasyonu ve Türkçe dersine yönelik tutum arasındaki ilişkiyi incelemektir. Araştırma ilişkisel tarama yoluyla gerçekleştirilmiştir. Araştırmanın çalışma grubu, 385 öğrenciden oluşmaktadır. Verilerin toplanmasında "Okuma Motivasyonu Ölçeği", "Türkçe Dersine Yönelik Tutum Ölçeği" ve "Okuduğunu Anlama Testi" kullanılmıştır. Verilerin toplanması aşamasında, ölçek sahibi araştırmacılardan, MEB'den ve Etik Kuruldan gerekli izinler alınmıştır. Yapılan analizler sonucunda beşinci sınıf öğrencilerinin okuduğunu anlama seviyelerinin orta düzeyde, okuma motivasyonu ve Türkçe dersine yönelik puanlarının ise yüksek düzeyde olduğu tespit edilmiştir. Katılımcıların okuduğunu anlama, okuma motivasyonu ve Türkçe dersine yönelik tutum puanları cinsiyete göre anlamlı farklılık göstermektedir. Bu farklılık kızların lehinedir. Elde edilen bir başka bulguya göre, içsel motivasyon ve Türkçe dersine yönelik tutumun okuduğunu anlamayı olumlu yönde etkilediği yönündedir. Bu durum içsel motivasyon ve tutumun öğrencilerin okuduğunu anlamak için ihtiyaçları olan bilişsel ve duyuşsal becerileri geliştirdiğini göstermektedir. Bununla birlikte dışsal motivasyonun okuduğunu anlama üzerinde anlamlı bir etkiye sahip olmadığı belirlenmiştir.
\end{abstract}

Anahtar Kelimeler: Türkçe öğretimi, okuduğunu anlama, okuma motivasyonu, Türkçe dersine yönelik tutum, beşinci sınıf öğrencileri

\section{The Relation Between Reading Comprehension, Reading Motivation, and Attitudes of Fifth Grade Students towards Turkish Course}

\begin{abstract}
Abstrece
The purpose of the present study was to examine the relationship between reading comprehension, reading motivation and attitudes towards the Turkish course of students. The study was conducted with the Correlational Survey Method. The Study Group consisted of 385 students. The "Reading Motivation Scale", "Attitude Scale Towards Turkish Course", and "Reading Comprehension Test" were used to collect the data. The required permissions were obtained from the researchers, the Ministry of National Education, and the Ethics Committee before the data collection stage. As a result of the analyses, it was determined that the reading comprehension level of the fifth-grade students was at a moderate level, and reading motivation and Turkish course scores were high. The reading comprehension, reading motivation, and attitude scores of the participants towards the Turkish course differed at significant levels according to gender. This difference was in favor of the female participants. According to another finding of the study, internal motivation and attitude towards the Turkish course affected reading comprehension positively. This shows that internal motivation and attitude improve students' cognitive and
\end{abstract}

\footnotetext{
* Doç. Dr., Aksaray Üniversitesi, Eğitim Fakültesi, Türkçe ve Sosyal Bilimler Eğitimi Bölümü, Aksaray, tuncayturkben57@gmail.com, ORCID: orcid.org/0000-0003-0167-4173

** Arş. Gör. Dr., Aksaray Üniversitesi, Eğitim Fakültesi, Eğitim Bilimleri Bölümü, Aksaray, cgundeger@gmail.com, ORCID: orcid.org/0000-0003-3572-1708
} 
affective skills, which are required to understand what they read. However, it was also found that external motivation did not have a significant effect on reading comprehension.

Keywords: Teaching Turkish, reading comprehension, reading motivation, attitudes towards Turkish course, fifth grade students

\section{Giriş}

Günümüzde değişen dünya koşullarıyla uyum sağlamanın yolu nitelikli bir ana dili eğitiminden geçmektedir. Bireyin hayatı algılaması, anlaması ve ona uyum sağlayabilmesi, Türkçe eğitimi ve öğretiminin niteliğiyle ve dolayısıyla dil becerileriyle doğrudan bağlantılıdır (Calp ve Calp, 2016, s.141). Nitekim Türkçe Dersi Öğretim Programı'nda (2019) dil becerileri ve yeterliliklerinin geliştirilmesi, diğer tüm alanlardaki öğrenme, kişisel ve sosyal gelişme ile mesleki becerileri edinmenin ön şartı olarak kabul edilmektedir.

Bireyin hayat boyu öğrenme sürecinde kullanabileceği en temel kritik dil becerilerinden biri okumadır. Bu nedenle de ilköğretim sürecinde okuma eğitiminin temelleri sağlam atılmalıdır. Okuma becerisi ile öğrenci farklı kaynaklara ulaşarak yeni bilgi, olay ve deneyimlerle karşılaşır. Bu beceri öğrenme, araştırma, yorumlama, tartışma ve eleştirel düşünmeyi de içine alan bir süreci içermektedir. Bu bağlamda, bireyin akademik yaşamı ve daha sonrasında başarılı olması, iyi gelişmiş bir okuma becerisine sahip olmasıyla mümkün olacaktır (Türkben, 2019, s.28).

Okuma, bireyin dilsel, zihinsel, sosyal ve kültürel birçok alanda gelişimine katkıda bulunur. Eğitim sürecinin merkezinde yer alan okuma, zor ve karmaşık bir sürecin yaşanmasını gerektirmektedir (Ülper, 2010, s.1). Okuma, bir yazıyı bütün bileşenleriyle görme, algılama, kavrama ve anlamlandırma etkinliği (Just ve Carpenter, 1980, s.332); yazılı dilin anlamlı bir şekilde yorumlanması (Harris ve Sipay, 1990); bilişsel davranışlarla psiko-motor becerilerin ortak çalışmasıyla yazılı sembollerden anlam çıkarma etkinliği (Demirel, 1999, s.59); yazar ve okur arasında aktif ve etkili bir iletişimi gerekli kılan dinamik anlam kurma süreci (Akyol, 2014, s.33) şeklinde tanımlanmaktadır. Yapılan tanımlardan da görüldüğü gibi okuma; görme, algılama, seslendirme, anlama, zihinde yapılandırma gibi göz, ses ve beynin ortaklaşa gerçekleştirdiği bütünsel bir eylemdir.

Okumanın temel amacı okunan metni anlamlandırmaktır. Okuduğunu anlama ise çok bileşenli ve karmaşık bir beceridir (National Reading Panel, 2000). Bu süreç farklı ögelerin, farklı bilgi türlerinin ve karmaşık zihinsel temsillerin katılımını gerektirmektedir (Yamaç ve Çeliktürk-Sezgin, 2018, s.227). Okuduğunu anlama, yazılı dille olan ilgi ve etkileşim sonucunda anlamın yapılandırıması, öze ulaşma (Sweet ve Snow, 2002, s. 25); okuyucunun metin ile etkileşime girerek anlamı oluşturduğu yapıcı bir süreci içermektedir (Durkin, 1993). Okuduğunu anlama sürecinde anlamı bulma, anlam üzerinde düşünme, nedenleri araştırma, sonuçlar çıkarma ve değerlendirmede bulunma vardır (Balcı, 2013, s.14).

Okuduğunu anlama sürecinde pek çok faktör etkilidir. Bunlardan bir tanesi de motivasyondur. Öğrencilerin öğrenme tercihleri ve akademik başarıları üzerinde motivasyonun etkisi vardır. Motivasyon, öğrencinin öğrenmeye, anlamaya ve çalışmaya istek duymasını sağlayan bir etkidir. "Okuma motivasyonu bireylerin okumaya ayıracakları zamanı, okuma eğilimlerini, okuma sürecinde gösterecekleri çabayı etkileyen; okumaya yönelik ilgi ve merakı oluşturan temel bir yapıdır" (Yıldız ve Aktaş, 2015, s.1350). Wang ve Guthrie'ye göre (2004) okuma motivasyonu, bireylerin okuma sürecine yönelmesini sağlayan içsel ve dışsal süreçlerdir. "Okuma motivasyonu öz yeterlik, içsel-dışsal motivasyon, değer, başarı hedefleri ve okumada sosyal motivasyon gibi boyutlardan oluşmaktadır. Öz yeterlik; okuma yeterliği ve zorlayıcı okuma olmak üzere iki ögeden oluşur. İçsel motivasyon ve öğrenme hedefleri, okuma merakı, okuma bağlılığı, okumanın önemi ve okuma işinden kaçınmadan oluşur. Dışsal motivasyon ve performans hedefleri, rekabet, tanınma ve not almayı içerir. Sosyal motivasyon da sosyal nedenler ve uyum olmak üzere iki alt öge içerir" (Wigfield ve Guthrie, 1997; akt. Yamaç ve Çeliktürk-Sezgin, 2018, s.229).

Alanyazında okuma üzerine yapılan çok sayıda çalışmada okuma motivasyonunun okuduğunu anlamayı açıklayan ve destekleyen bir yapı olduğu görülmektedir (Baker ve Wigfield, 1999; Batmaz ve Erdoğan, 2019; Becker vd., 2010; Guthrie vd., 2007; Retelsdorf, Köller ve Möller, 2011; Schaffner vd., 2013; Stutz vd., 2016; Taboada, Tonks, Wigfield ve Guthrie, 1997; Wigfield, Guthrie, Tonks ve 
Prencevich, 2004; Türkben, 2020; Ürün-Karahan ve Taşdan, 2016: Wang ve Guthrie, 2004; Wigfield ve Guthrie, 1997; Yamaç ve Çeliktürk-Sezgin, 2018; Yıldız, 2010; Yıldız ve Akyol, 2011; Yıldız, 2013). Yapılan çalışmaların çoğunda, içsel motivasyon ile okuduğunu anlama arasında pozitif yönde bir ilişkinin olduğu (Schallert ve Reed, 1997; Stutz vd., 2016; Taboada vd. 2009; Wang ve Guthrie, 2004; Yıldız ve Akyol, 2011) görülmektedir. Deci ve Ryan'a (1985) göre içsel motivasyonu yüksek öğrenciler okuma sürecinde karşılaştıkları zorlukların üstesinden gelmek için gerekli çözüm yollarını bulmaktadır. Diğer taraftan bazı çalışmalar ise dışsal motivasyon ve okuduğunu anlama arasında negatif ya da anlamsız ilişkiler göstermektedir (Stutz vd., 2016; Wang ve Guthrie, 2004). Yıldız ve Akyol (2011) ise yapmış oldukları çalışmada dışsal motivasyonun rekabet alt boyutu hariç negatif etki yaptığını saptamışlardır. Vansteenkiste, Lens ve Deci (2006) de yaptıkları çalışmada içsel motivasyonlu öğrencilerin dışsal motivasyonlu öğrencilere göre, okuduklarını hatırlamada ve anlamada daha başarılı olduklarını tespit etmişlerdir.

Öğrenciler, derslerde dersi sevme, derse karşı ilgili olma, derse karşı olumlu tutum geliştirme gibi birtakım duyuşsal özellikleri de kazanabilmektedirler (Kazazoğlu, 2013, s.295). Tutum kavramı, "bireyin ilgili durum ya da nesnelere ilişkin tepkisi üzerinde dinamik ya da yönlendirici bir etki yapan, yaşantı içinde biçimlenmiş bir zihinsel ya da sinirsel hazırlık durumu" (Allport, 1935; akt. Tavşancıl, 2002 , s. 65); herhangi bir kişiye, objeye, olay ya da duruma karşı verilen olumlu ya da olumsuz duygusal tepkiler (Balcı, 2013, s.26) olarak tanımlanabilir. "Eğitim ortamlarında öğrencilerin sahip olduğu olumlu veya olumsuz tutumlar, onların düşüncelerini (örneğin derse katılmanın anlamlı ya da anlamsız olduğunu düşünme), hissettikleri duyguları (örneğin dersi sevme ya da sevmeme) ve davranışta bulunma eğilimlerini (örneğin derse katılma ya da katılmama) etkilemektedir" (Kağıtçıbaşı, 1999; akt. Fidan ve Eren, 2017, s.482).

Öğrencilerin temel dil becerilerini kazanmaları ve bu becerileri geliştirerek bilişsel, duyuşsal ve sosyal gelişimlerini sağlamaları açısından Türkçe derslerinden faydalanılmaktadır. Derse karşı geliştirilen tutum, merkezi duyuşsal değişkenlerden biri olarak öğrenmeyi arttırmada önemli bir işleve sahiptir (Brown, 2001; Francis ve Greer, 1999; Fidan ve Eren, 2017; Karasakaloğlu ve Saracaloğlu, 2009; Kaya, Arslantaş ve Şimşek, 2009). Alanyazında öğrencilerin Türkçe dersine yönelik tutumun akademik başarı, okuduğunu anlama düzeyi, motivasyon ile ilişkisi üzerine yapılan çalışmalar mevcuttur (Ateş, 2008; Erdem ve Gözüküçük, 2013; Kaya, 2011; Kazazoğlu, 2013; Öztürk, 2010). Türkçe dersine ilişkin olumlu tutum, bu derse ilişkin motivasyonu da pozitif yönde etkilemektedir (Erdem ve Gözüküçük, 2013). Alanyazında okuduğunu anlama, okuma motivasyonu ve Türkçe dersine yönelik tutum ile ilgili çalışmalar mevcuttur. Ancak okuduğunu anlama ile okuma motivasyonu ve Türkçe dersine yönelik tutum arasındaki ilişkiyi inceleyen yeterli çalışmanın olmadığı görülmektedir. Bu çalışmanın amacı da bu değişkenler arasındaki ilişkiyi incelemektir. Çalışmanın alt problemleri şu şekildedir:

1. Beşinci sınıf öğrencilerinin okuma motivasyonu (içsel motivasyon ve dışsal motivasyon), Türkçe dersine yönelik tutum ve okuduğunu anlama düzeyleri nasıldır?

2. Beşinci sınıf öğrencilerinin okuma motivasyonu, Türkçe dersine yönelik tutum ve okuduğunu anlama düzeyleri cinsiyete göre nasıl bir farklılık göstermektedir?

3. Beşinci sınıf öğrencilerinin okuma motivasyonları, Türkçe dersine yönelik tutumları ve okuduğunu anlama düzeyleri arasında nasıl bir ilişki vardır?

4. Beşinci sınıf öğrencilerinin okuma motivasyonları, Türkçe dersine yönelik tutumları, okuduğunu anlama düzeylerini nasıl yordamaktadır?

\section{Araştırmanın Modeli}

\section{Yöntem}

Bu araştırma, beşinci sınıf öğrencilerinin okuduğunu anlama, okuma motivasyonu ve Türkçe dersine yönelik tutum arasındaki ilişkileri ve bağlantıları incelemeyi amaçlamaktadır. Bu nedenle bu araştırmada ilişkisel araştırma yöntemine başvurulmuştur. iliş̧kisel araştırmalarda, iki ya da daha çok değişkenin birlikte değişim derecesi incelenmektedir (Karasar, 2013). 


\section{Çalışma Grubu}

Araştırmanın çalışma grubunu, 2019-2020 eğitim-öğretim yılı güz döneminde Aksaray il merkezinde öğrenim gören 385 beşinci sınıf öğrencisi oluşturmaktadır. Katılımcılar, basit seçkisiz örnekleme yöntemiyle belirlenmiştir. Sadece bir öğrencinin veri setindeki cinsiyet bilgisini boş bıraktığı tespit edilmiş, bu yüzden bu öğrenciye ait veri seti kapsam dışı bırakılmıștır. 384 öğrencinin verileri üzerinden istatiksel analizler yapılmıştır. Uygulama yapılan öğrencilerin $\% 52,1^{\prime} i$ (f: 200 ) erkek; \%47,9'u (f: 184) ise kız öğrencilerden oluşmaktadır.

\section{Veri Toplama Araçları}

Bu çalışmada, Okuma Motivasyonu Ölçeği (OMÖ), Okuduğunu Anlama Testi (OAT) ve Türkçe Dersine Yönelik Tutum Ölçeği (TDYTÖ) veri toplama araçları olarak kullanılmıştır.

\section{Okuma Motivasyonu Ölçeği (OMÖ)}

Wang ve Guthrie (2004) tarafından geliştirilmiş; Yıldız (2010) tarafından Türk kültürüne uyarlanmış iki boyutlu dörtlü Likert tipinde bir ölçektir. Yıldız (2010) ölçeğin yapı geçerliğini Doğrulayıcı Faktör Analizi (DFA) ile belirlemiştir. DFA sonuçlarına göre, iki boyutlu bu ölçeğin model-veri uyumunun iyi düzeyde olduğu görülmüştür $\left(X^{2}=457.77, p=0.000, s d=182, X^{2} / s d=2.51 ; R M S E A=0.051, R M R\right.$ $=0.038, \mathrm{GFI}=0.93, \mathrm{AGFI}=0.91, \mathrm{CFI}=0.89, \mathrm{NFI}=0.83$ ). Ölçeğin güvenirliğini belirlemede Cronbach Alfa iç tutarlılık katsayısı; ölçeğin tümü için 0,86 ; içsel motivasyon alt boyutu için 0,68 ve dışsal motivasyon için ise 0,82 olarak hesaplanmıştır. Ölçeğin güvenirliğini belirlemede test-tekrar test yöntemi de işe koşulmuş; içsel ve dışsal motivasyon alt boyutları için iki uygulama arasındaki ilişki yüksek bulunmuştur $\left(r_{\text {içsel }}=0.73, p<0.01 ; r_{\text {dısssal }}=0.810, p<0.01\right)$. Bu çalışmada ise toplanan verinin modele uyumu DFA ile incelenmiş ve güvenirlik için de Cronbach Alfa katsayısı hesaplanmıştır. DFA varsayımlarının sınanması sonrasında gerçekleştirilen analiz sonuçlarına göre, model-veri uyumunun iyi düzeyde olduğu ve sonuçların Yıldız'ın (2010) DFA sonuçları ile örtüştüğü söylenebilir $\left(X^{2}=457.26, p=0.000\right.$, $s d=174, X^{2}$ / sd = 2.56; RMSEA =0.064, RMR = 0.039, SRMR =0.058, GFI $=0.90, \mathrm{AGFI}=0.87, \mathrm{CFI}=0.95, \mathrm{NFI}=0.92$, $\mathrm{NNFI}=0,94)$. Hesaplanan Cronbach Alfa katsayıları ise, ölçeğin tümü için 0,87 ; içsel motivasyon alt boyutu için 0,77 ve dışsal motivasyon alt boyutu için de $0,83^{\prime}$ tür. Buna göre alt boyutlara ilişkin güvenirlik katsayılarının yeterli düzeyde olduğu ve Yıldız'ın (2010) güvenirlik sonuçlarıyla uyumlu olduğu söylenebilir.

\section{Okuduğunu Anlama Testi (OAT)}

Yıldız (2010) tarafından geliştirilmiş bu testin Cronbach Alfa katsayısı 0,81'dir. Maddelere ait ayırt edicilik indeksleri madde-toplam korelasyonu yardımıyla hesaplanmış; ayrıca alt-üst grup analizi uygulanarak maddelerin ayırt edicilikleri test edilmiştir. Analiz sonuçlarına göre, maddelerin ayırt edicilik düzeylerinin 0,31 ile 0,52 arasında olduğu; alt - üst \%27'lik dilimde yer alan öğrencileri ayırt etmede de yeterli olduğu belirlenmiştir. Bu çalışmada ise, teste ait Cronbach Alfa değeri 0,80 olarak hesaplanmış ve alt-üst grup madde analizi sonuncunda da maddelerin tümünün ayırt ediciliklerinin 0,01 hata düzeyinde anlamlı olduğu sonucuna ulaşılmıştır.

\section{Türkçe Dersine Yönelik Tutum Ölçeği (TDYTö)}

Topçuoğlu-Ünal ve Köse (2014) tarafından geliştirilmiş beşli Likert türünde bir ölçektir. 40 maddelik taslak madde yazımından sonra kapsam geçerliği için uzman görüşleri alınmış ve taslak ölçek madde sayısı 35'e düşsmüştür. Ön uygulama verisi üzerinden gerçekleştirilen Açımlayıcı Faktör Analizi (AFA) sonuçlarına göre, 27 maddelik ölçeğin üç boyutlu olduğuna karar verilmiş ve bu boyutlar alanyazın desteği ile isimlendirilmiştir. Ölçeğin tümü toplam varyansın $\% 52,746$ 'sını karşılamaktadır. DFA sonucunda ise model veri uyumunun iyi olduğu görülmüştür $X^{2}=610,08 ; s d=321 ; \chi^{2} / s d=1,90$; RMSEA $=0,066 ; \mathrm{GFI}=0,85 ; \mathrm{SRMR}=0,072 ; \mathrm{CFI}=0,86 ; \mathrm{NNFI}=0,85)$. Güvenirlik analizi sonucunda Cronbach Alfa iç tutarlılık katsayısı hesaplanmış; bu değer ölçeğin tümü için 0,92; Derse Yönelik illgi ve Sevgi boyutu için 0,93; Derse Iliş̧in Olumsuz Tutumlar boyutu için 0,84 ve Derse Yönelik Etkinlikler boyutu için $0,73^{\prime}$ tür. Bu çalışmada ise toplanan verinin modele uyumu DFA ile incelenmiş ve güvenirlik için de Cronbach Alfa katsayısı hesaplanmıştır. DFA varsayımlarının sınanması sonrasında 
gerçekleştirilen analiz sonuçlarına göre, model-veri uyumunun iyi düzeyde olduğu ve sonuçların Topçuoğlu Ünal ve Köse' nin (2014) DFA sonuçları ile örtüştüğg̈ söylenebilir $\left(X^{2}=1002,68, p=0.000\right.$, sd $=321, \mathrm{X}^{2} / \mathrm{sd}=3,12 ; \mathrm{RMSEA}=0.074, \mathrm{RMR}=0.081, \mathrm{SRMR}=0.063, \mathrm{GFI}=0.84, \mathrm{AGFI}=0.81, \mathrm{CFI}=0.94$, $\mathrm{NFI}=0.92, \mathrm{NNFI}=0,94)$. Hesaplanan Cronbach Alfa katsayıları ise, ölçeğin tümü için 0,90; Derse Yönelik illgi ve Sevgi boyutu için 0,88; Derse îlişkin Olumsuz Tutumlar boyutu için 0,76 ve Derse Yönelik Etkinlikler boyutu için $0,66^{\prime}$ dır. Buna göre alt boyutlara ilişkin güvenirlik katsayılarının yeterli düzeyde olduğu ve Topçuoğlu Ünal ve Köse'nin (2014) güvenirlik sonuçlarıyla uyumlu olduğu söylenebilir.

\section{Verilerin Analizi}

Elde edilen veri Excel'e aktarılmış; ters puanlanan maddelerin bulunduğu tutum ölçeğindeki maddelerin ters puanlaması gerçekleştirilmiş; veri setindeki sadece bir öğrencinin cinsiyet bilgisini boş bıraktığı görülmüş ve bu veri setten çıkarılmıştır. Ardından çoklu regresyon analizi varsayımları sınanmış; bu amaçla tek yönlü ve çok yönlü uç değerler hesaplanmış ve bu değerlere sahip bireyler veri setinden çıkarılmıştır. Birinci alt problemin çözümünde betimsel istatistiklerden yararlanılmıştır. Ortalama, mod, medyan değerlerinin birbirine yakın olması dağılımın normal olduğuna işaret etmektedir. Ayrıca çarpıklık ve basıklık katsayıları $-1,1$ aralığında ise dağılım normal dağılım özelliği göstermektedir (Büyüköztürk, 2008).

İkinci alt problemin çözümünde cinsiyet değişkeninin alt kategorilerinde bağımlı değişkenlerin nasıl bir dağılım gösterdiği betimsel istatistikler ve Kolmogorov-Smirnov testi ile incelenmiş; Okuduğunu Anlama Testi puanlarının dağılımının normallik varsayımı sağladığı; diğer değişkenlere ait puanların normal dağılım göstermediği görülmüştür. Bu bulguya dayanarak cinsiyete dayalı karşılaştırmada Okuduğunu Anlama Testi için bağımsız örneklemler $t$ testi; diğer puanlar için ise MannWhitney $U$ testi uygulanmışır. Mann-Whitney $U$ testi normallik varsayımı gerektirmeyen parametrik olmayan bir tekniktir ve bağımsız örneklemlerin karşılaştırılmasında kullanılır (Büyüköztük, 2009). Üçüncü alt problemin çözümünde değişkenlerin tümünün normallik varsayımını sağlaması sebebiyle, değişkenlerin ikili kombinasyonları arasındaki ilişkinin belirlenebilmesi amacıyla, Pearson korelasyon katsayısı hesaplanmıştır.

Dördüncü alt problemin çözümünde ise regresyon analizinin varsayımları olan çoklu bağlanım ve tekillik sorunu kontrol edilmiş; motivasyon ile içsel-Dışsal motivasyon alt boyutlarının çoklu bağlanım sorunu teşkil edeceği görülmüş; bu nedenle analize içsel ve dışsal motivasyon alınmış; motivasyon toplam puanları analiz dışında tutulmuştur. Çoklu regresyon analizi varsayımları olan çoklu bağlanım ve tekillik, Tolerans değerleri, varyans büyütme faktörleri ve durum indeksleri ile de incelenmiş; veri setinde herhangi bir çoklu bağlanım ve/veya tekillik sorunu olmadığı görülmüştür. Analiz sonucu $R, R^{2}$ değerleri yorumlanmış; bağımsız değişkenlerin göreli önem sırası verilmiş ve regresyon eşitliği oluşturulmuştur. Analizlerin tümü paket programda gerçekleştirilmiştir.

\section{Araştırma ve Yayın Etiği}

Bu çalışmada "Yükseköğretim Kurumları Bilimsel Araştırma ve Yayın Etiği Yönergesi" kapsamında uyulması belirtilen tüm kurallara uyulmuştur. Yönergenin ikinci bölümü olan "Bilimsel Araştırma ve Yayın Etiğine Aykırı Eylemler" başlığı altında belirtilen eylemlerden hiçbiri gerçekleştirilmemiştir.

\section{Etik Kurul İzni}

Yukarıda geçerlik ve güvenirliklerine ilişkin bilgiler sunulan üç ölçeğin bu araştırmada kullanılması için ölçek sahibi araştırmacılardan, MEB'den ve Etik Kuruldan gerekli izinler alınmıştır. Veriler 2019-2020 güz döneminde Aksaray il merkezindeki okullardan toplanmıştır. Araştırmanın bağımsız değişkenlerine ilişkin demografik bilgiler ise araştırmacılar tarafından oluşturulan bir anket formu yardımıyla elde edilmiştir. Uygulamalar, iki ders saati içerisinde, öğrencilerin öğretmenleri yardımıyla araştırmacılar tarafından yapılmıştır.

Kurul adı = Aksaray Üniversitesi İnsan Araştırmaları Etik Kurulu

Karar tarihi $=22.06 .2020$

Belge sayı numarası $=06$ 


\section{Bulgular}

Birinci alt problemin çözümünde, beşinci sınıf öğrencilerinin okuma motivasyonu (içsel motivasyon ve dışsal motivasyon), Türkçe Dersine yönelik tutum ve okuduğunu anlama düzeylerinin belirlenebilmesi amacıyla, beşinci sınıf öğrencilerinin içsel-dışsal ve genel motivasyon puanları, Türkçe dersine yönelik tutum puanları ve okuduğunu anlama düzeylerini belirlemeye yönelik başarı puanlarının betimsel istatistikleri hesaplanmış; istatistikler aşağıda Tablo 1'de sunulmuştur.

Tablo 1'e göre, Okuma Motivasyonu Ölçeği İçsel Motivasyon alt boyutundan alınan puanların ortalaması, ortancası ve modu sırasıyla 23,24 ve $25^{\prime}$ tir. Bu değerler arasındaki yakınlık puanların normal dağıldığına işaret etmektedir (Büyüköztürk, 2008). Ölçeğin bu alt boyutundan alınan en düşük puan 13 ve en yüksek puan 28'dir. Dışsal Motivasyon alt boyutundan alınan puanların ortalaması, ortancası ve modu sırasıyla 46, 48 ve 51'dir. Ölçeğin bu alt boyutundan alınan en düşük puan 27 ve en yüksek puan $56^{\prime}$ dır. Öğrencilerin Okuma Motivasyonu Ölçeği'nin tümünden aldıkları puanların ortalaması, ortancası ve modu sırasıyla 70,72 ve 75'tir. Ölçekten alınan en düşük puan 43 ve en yüksek puan 84 'tür. Buna göre öğrencilerin içsel, dışsal ve genel motivasyon puanlarının yüksek olduğu söylenebilir.

Tablo 1'e göre öğrencilerin Türkçe Dersine Yönelik Tutum Ölçeği'nden almış oldukları puanların ortalaması, ortancası ve modu sırasıyla 107, 109 ve 113'tür. Ölçekten elde edilen puanların en küçük değeri 62 iken en yüksek değerinin 133 olduğu görülmektedir. Ölçeğe ait puanların standart sapması, diğer standart sapma değerlerine kıyasla daha yüksek hesaplanmıştır ve bu durum öğrencilerin tutum puanları bakımından iyi bir şekilde ayrıştığı ve heterojen bir yapı gösterdiği anlamına gelmektedir. Ayrıca öğrencilerin tutum puanlarının da yüksek olduğu görülmektedir. Öğrencilerin okuduğunu anlama düzeylerinin ölçüldüğü başarı testi puanlarının ortalaması, ortancası ve modu ise sırasıyla 18, 18 ve 17 'dir. Testten alınan en düşük puan 3 ve en yüksek puan $28^{\prime}$ dir. Bu bulguya dayanarak öğrencilerin okuduğunu anlama düzeylerinin orta derecede olduğu yorumu yapılabilir. Ayrıca Tablo 1'deki çarpıklık ve basıklık katsayıları incelendiğinde bu katsayıların $(-1,1)$ aralığında yer aldığı görülmektedir. Buna göre tüm puanların normal dağılım özelliği gösterdiği söylenebilir (Büyüköztürk, 2008).

Tablo 1.

Betimsel istatistikler $(n=384)$

\begin{tabular}{|c|c|c|c|c|c|c|c|c|}
\hline & $\overline{\mathbf{x}}$ & Medyan & Mod & $\begin{array}{l}\text { Standart } \\
\text { Sapma }\end{array}$ & $\begin{array}{c}\text { En } \\
\text { Küçük } \\
\text { Değer }\end{array}$ & $\begin{array}{c}\text { En } \\
\text { Büyük } \\
\text { Değer }\end{array}$ & $\begin{array}{l}\text { Çarpıklık } \\
\text { Katsayısı } \\
\text { (St. Hata) }\end{array}$ & $\begin{array}{r}\text { Basıklık } \\
\text { Katsayısı } \\
\text { (St. Hata) }\end{array}$ \\
\hline $\begin{array}{l}\text { İçsel } \\
\text { Motivasyon }\end{array}$ & 23,38 & 24 & 25 & 3,60 & 13 & 28 & $\begin{array}{c}-0,72 \\
(0,13)\end{array}$ & $\begin{array}{r}-0,05 \\
(0,25)\end{array}$ \\
\hline $\begin{array}{l}\text { Dışsal } \\
\text { Motivasyon }\end{array}$ & 46,33 & 48 & 51 & 6,05 & 27 & 56 & $\begin{array}{l}-0,83 \\
(0,13)\end{array}$ & $\begin{array}{r}-0,09 \\
(0,25)\end{array}$ \\
\hline Motivasyon & 69,71 & 72 & 75 & 8,57 & 43 & 84 & $\begin{array}{l}-0,84 \\
(0,13)\end{array}$ & $\begin{array}{r}0,26 \\
(0,25)\end{array}$ \\
\hline $\begin{array}{l}\text { Türkçe } \\
\text { Dersine } \\
\text { Yönelik } \\
\text { Tutum }\end{array}$ & 106,54 & 109 & 113 & 14,87 & 62 & 133 & $\begin{array}{l}-0,67 \\
(0,13)\end{array}$ & $\begin{array}{r}-0,12 \\
(0,25)\end{array}$ \\
\hline $\begin{array}{l}\text { Okuduğunu } \\
\text { Anlama } \\
\text { Düzeyi }\end{array}$ & 17,61 & 18 & 17 & 5,03 & 3 & 28 & $\begin{array}{l}-0,31 \\
(0,13)\end{array}$ & $\begin{array}{r}-0,32 \\
(0,25)\end{array}$ \\
\hline
\end{tabular}

İkinci alt problemin çözümünde, beşinci sınıf öğrencilerinin okuma motivasyonu, Türkçe dersine yönelik tutum ve okuduğunu anlama düzeylerinin cinsiyete göre nasıl bir farklııı gösterip göstermediğini belirleyebilmek amacıyla öncelikle varsayımlar sınanmıştır. Öğrencilerin içsel ve dışsal motivasyon puanlarının, Türkçe dersine yönelik tutum puanlarının cinsiyet değişkeninin alt 
kategorilerinde, çarpıklık ve basıklık katsayıları ile Kolmogorov-Smirnov Testi sonuçlarına göre, normal dağılım özelliği göstermediği; öğrencilerin başarı testinden aldıkları puanların ise cinsiyet değişkeninin alt kategorilerinde normal dağılım özelliği gösterdiği belirlenmiştir. Bu nedenle içsel ve dışsal motivasyon puanlarının ve Türkçe dersine yönelik tutum puanlarının cinsiyete göre karşılaştırılmasında Mann-Whitney U Testi; başarı testi puanlarının karşılaştırılmasında ise bağımsız örneklemler için t testi işe koşulmuş; analiz sonuçları sırasıyla Tablo 2 ve Tablo 3'te özetlenmiştir.

Tablo 2.

Cinsiyete Göre U Testi Sonuçları ( $n=384)$

\begin{tabular}{|c|c|c|c|c|c|c|}
\hline $\begin{array}{l}\text { Bağımlı } \\
\text { Değişken }\end{array}$ & Cinsiyet & $n$ & $\begin{array}{c}\text { Sıra } \\
\text { Ortalaması }\end{array}$ & $\begin{array}{c}\text { Sıra } \\
\text { Toplamı }\end{array}$ & U & $p$ \\
\hline \multirow{2}{*}{$\begin{array}{l}\text { İçsel } \\
\text { Motivasyon }\end{array}$} & Erkek & 200 & 177,31 & 35462,50 & \multirow{2}{*}{15362,50} & \multirow[t]{2}{*}{0,00} \\
\hline & KIz & 184 & 209,01 & 38457,50 & & \\
\hline \multirow{2}{*}{$\begin{array}{l}\text { Dışsal } \\
\text { Motivasyon }\end{array}$} & Erkek & 200 & 176,91 & 35382,00 & \multirow{2}{*}{15282,00} & \multirow[t]{2}{*}{0,00} \\
\hline & KIz & 184 & 209,45 & 38538,00 & & \\
\hline \multirow[t]{2}{*}{ Motivasyon } & Erkek & 200 & 174,01 & 34801,50 & \multirow{2}{*}{14701,50} & \multirow[t]{2}{*}{0,00} \\
\hline & KIZ & 184 & 212,60 & 39118,50 & & \\
\hline \multirow[t]{2}{*}{ Tutum } & Erkek & 200 & 166,06 & 33211,50 & \multirow{2}{*}{13111,50} & \multirow[t]{2}{*}{0,00} \\
\hline & $\mathrm{K} \mathrm{Iz}$ & 184 & 221,24 & 40708,50 & & \\
\hline
\end{tabular}

Tablo 2'ye göre, kız ve erkek öğrencilerin içsel ve dışsal motivasyon puanları ile Türkçe dersine yönelik tutum puanlarının 0,01 hata düzeyinde anlamlı şekilde farklılaştığı görülmektedir $(p<0,01)$. Sıra ortalamaları incelendiğinde bu farklılıkların tüm bağımlı değişkenlerde kız öğrencilerin lehine olduğu göze çarpmaktadır. Buna göre, kız öğrencilerin içsel ve dışsal motivasyonlarının ve Türkçe dersine yönelik tutumlarının erkek öğrencilere kıyasla manidar şekilde daha yüksek olduğu söylenebilir.

Tablo 3.

Okuduğunu Anlama Testi Puanlarının Cinsiyete Göre t Testi Sonuçları (n=384)

\begin{tabular}{|c|c|c|c|c|c|c|c|}
\hline Bağımlı Değişken & Cinsiyet & $\mathrm{N}$ & $\overline{\mathbf{x}}$ & $S$ & $\mathrm{sd}$ & $\mathrm{t}$ & $p$ \\
\hline \multirow[t]{2}{*}{ Test Puanı } & Erkek & 200 & 16,74 & 5,172 & \multirow[t]{2}{*}{382} & \multirow[t]{2}{*}{3,61} & \multirow[t]{2}{*}{0,00} \\
\hline & KIz & 184 & 18,56 & 4,695 & & & \\
\hline
\end{tabular}

Tablo 3'e göre öğrencilerin okuduğunu anlama testi puanları cinsiyete göre 0,01 hata düzeyinde manidar farklılık göstermekte ve bu farklılık kız öğrenciler lehinedir. Buna göre, kız öğrencilerin okuduğunu anlama düzeylerinin, erkek öğrencilere kıyasla istatistiksel olarak anlamlı şekilde daha yüksek olduğu söylenebilir.

Üçüncü alt problemin çözümünde, beşinci sınıf öğrencilerinin okuma motivasyonları, Türkçe dersine yönelik tutumları ve okuduğunu anlama düzeyleri arasında nasıl bir ilişki olduğunun belirlenebilmesi amacıyla, beşinci sınıf öğrencilerinin okuma motivasyon puanları, Türkçe dersine yönelik tutum puanları ve okuduğunu anlama düzeylerini ölçen başarı testi puanlarının betimsel istatistikleri ile çarpıklık-basıklık katsayılarına göre normal dağılım özelliği gösterdiği görülmüş; bu nedenle değişkenler arasındaki ikili ilişkiler Pearson korelasyon katsayısı ile incelenmiş; analiz sonuçları Tablo 4'te sunulmuştur.

Tablo 4.

Değişkenler Arasındaki ikili iliş̧kiler ( $n=384)$

\begin{tabular}{lccccc}
\hline Değişkenler & Başarı & $\begin{array}{c}\text { İçsel } \\
\text { Motivasyon }\end{array}$ & $\begin{array}{c}\text { Dışsal } \\
\text { Motivasyon }\end{array}$ & Motivasyon & Tutum \\
\hline Başarı & 1,00 & $0,57^{* *}$ & $0,33^{* *}$ & $0,47^{* *}$ & $0,33^{* *}$ \\
\hline İçsel Motivasyon & & 1,00 & $0,55^{* *}$ & $0,81^{* *}$ & $0,42^{* *}$
\end{tabular}




\begin{tabular}{lccc}
\hline Dişsal Motivasyon & 1,00 & $0,94^{* *}$ & $0,42^{* *}$ \\
\hline Motivasyon & & 1,00 & $0,48^{* *}$ \\
\hline Tutum $\quad{ }^{* *} p<0,01$ & & & 1,00 \\
\hline
\end{tabular}

Tablo 4'te tüm değişkenler arasındaki ikili ilişkilerin 0,01 hata düzeyinde manidar olduğu görülmektedir. Tablo 4'e göre, öğrencilerin okuduğunu anlama düzeylerini ölçen başarı testi puanları ile içsel motivasyon puanları arasında pozitif yönde ve orta düzeyde; öğrencilerin okuduğunu anlama düzeylerini ölçen başarı testi puanları ile dışsal motivasyon puanları arasında orta altı düzeyde ve pozitif yönde; öğrencilerin okuduğunu anlama düzeylerini ölçen başarı testi puanları ile motivasyon puanları arasında orta düzeyde ve pozitif yönde; öğrencilerin okuduğunu anlama düzeylerini ölçen başarı testi puanları ile Türkçe dersine yönelik tutum puanları arasında orta altı düzeyde pozitif yönde bir ilişki vardır. Öğrencilerin içsel motivasyon puanları ile dışsal motivasyon puanları arasında orta düzeyde ve pozitif yönde; öğrencilerin içsel motivasyon puanları ile motivasyon puanları arasında yüksek düzeyde ve pozitif yönde; öğrencilerin içsel motivasyon puanları ile Türkçe dersine yönelik tutum puanları arasında orta düzeyde ve pozitif yönde bir iliş̧i olduğu belirlenmiştir. Dışsal motivasyon ile motivasyon arasında oldukça yüksek düzeyde ve pozitif yönde; dışsal motivasyon ile tutum puanları arasında orta düzeyde ve pozitif yönde ve son olarak motivasyon puanları ile tutum puanları arasında da orta düzeyde ve pozitif yönde bir ilişki olduğu görülmektedir.

Dördüncü alt problemin çözümünde, beşinci sınıf öğrencilerinin okuma motivasyonları, Türkçe dersine yönelik tutumları, okuduğunu anlama düzeylerini nasıl yordadığını belirleyebilmek amacıyla değişkenler arasındaki ikili ilişkiler incelenmiştir. Tablo 4'te değişkenler arasında 0,01 hata düzeyinde manidar ilişkiler olduğu görülmektedir. İçsel ve dışsal motivasyon puanlarının motivasyon puanları ile 0,80 üzerinde korelasyon vermesi çoklu bağlanım ve/veya tekillik sorununa işaret etmektedir. Bu noktada öğrencilerin okuduğunu anlama başarı testinden almış oldukları puanların yordanmasında, öğrencilerin içsel motivasyonları, dışsal motivasyonları ve Türkçe dersine yönelik tutum puanları analize alınmış; motivasyon puanları analiz dışına çıkarılmıştır. Regresyon analizi sonucunda Tolerans değerleri 0,20'den büyük; varyans büyütme faktörleri 10'dan düşük ve durum indeksleri de 30'dan küçük hesaplanmıştır. Büyüköztürk'e (2009) göre bu durum veri setinde herhangi bir çoklu bağlanım ve/veya tekillik sorunu olmadığını göstermektedir. Regresyon analizi sonuçları Tablo 5 'te sunulmuştur.

Tablo 5.

Okuduğunu Anlamaya ilişkin Regresyon Analizi Sonuçları

\begin{tabular}{lccccc}
\hline Değişken & $\mathrm{B}$ & Standart Hata & $\beta$ & $\mathrm{t}$ & $\mathrm{p}$ \\
\hline Sabit & $-3,241$ & 1,905 & - & $-1,701$ & 0,090 \\
\hline İçsel Motivasyon & 0,726 & 0,072 & 0,519 & 10,017 & 0,000 \\
\hline Dışsal Motivasyon & $-0,004$ & 0,043 & $-0,005$ & $-0,096$ & 0,923 \\
\hline Tutum & 0,038 & 0,016 & 0,113 & 2,363 & 0,019 \\
\hline $\mathrm{R}=0,574$ & $\mathrm{R}^{2}=0,329$ & & & & \\
\hline $\mathrm{F}_{(3,380)}=62,180$ & $\mathrm{p}=0,000$ & & & & \\
\hline
\end{tabular}

Tablo 5’e göre, içsel motivasyon, dışsal motivasyon ve Türkçe dersine yönelik tutum puanları, okuduğunu anlama testi başarı puanları ile orta düzeyde ve pozitif yönde bir ilişki vermektedir $(R=$ 0,$\left.57 ; R^{2}=0,33 ; p<0,01\right)$. Bu üç değişken ile okuduğunu anlama başarı testi puanlarındaki değişkenliğin \%33'ünü açıklanmaktadır. Standartlaştırımış Beta katsayılarına göre, yordayıcı değişkenlerin okuduğunu anlama üzerindeki önem sıralaması içsel motivasyon, tutum ve dışsal motivasyon şeklindedir. Bir başka deyişle, okuduğunu anlama üzerindeki en etkili değişken içsel motivasyon; onu takiben sırasıyla Türkçe dersine yönelik tutum ve dışsal motivasyondur. Analiz sonucu hesaplanan regresyon katsayılarının önemlilikleri incelendiğinde ise içsel motivasyon ve tutumun okuduğunu anlama üzerinde manidar bir etkiye sahip olduğu görülmektedir $(p<0,05)$. Bununla birlikte dışsal motivasyon okuduğunu anlama üzerinde anlamlı bir etkiye sahip değildir. Buna göre okuduğunu 
anlamanın yordanmasına ilişkin regresyon eşitliği aşağıdaki gibi oluşturmak mümkündür. Bu eşitlik yardımıyla içsel motivasyon, dışsal motivasyon ve Türkçe dersine yönelik puanı bilinen öğrencinin okuduğunu anlama başarı düzeyi hesaplanabilecektir.

Okuduğunu Anlama $=-3,241+(0,73 *$ içsel Motivasyon $)+(-0,004 *$ Dışsal Motivasyon $)+$ (0,038*Tutum)

İ̧sel ve dışsal motivasyon ölçeğinin alt boyutlarından alınan puanların okuduğunu anlama düzeylerini nasıl yordadığının belirlenebilmesi amacıyla İlgi, Merak, Tanınma, Sosyal, Rekabet, Uyum alt ölçek puanları ve Türkçe dersine yönelik tutum ölçeğinden elde edilen puanlar bağımsız; okuduğunu anlama başarı testi puanları bağımlı değişken alınarak bir regresyon analizi daha gerçekleştirilmiştir. Bu alt boyutların bir önceki regresyon analizinde tümünün ele alınamamasının sebebi değişkenlerin içsel veya dışsal motivasyon ile 0,80 üstünde bir korelasyona sahip olmaları ve çoklu bağlanım/tekillik problemi ortaya çıkarmalarıdır. Bu nedenle ayrı bir analizde ele alınan bu değişkenler ile değişkenlerin bağımlı değişken üzerindeki etkisi ve göreli önemleri Tablo 6 'da sunulmuştur. Regresyon analizi sonucunda Tolerans değerleri 0,20'den büyük; varyans büyütme faktörleri 10'dan düşük ve durum indeksleri de 30'dan küçük hesaplanmıştır. Büyüköztürk'e (2009) göre bu durum veri setinde herhangi bir çoklu bağlanım ve/veya tekillik sorunu olmadığını göstermektedir.

Tablo 6.

Alt Ölçek Puanlarıla Uygulanan Regresyon Analizi Sonuçları

\begin{tabular}{lccccc}
\hline Değişken & B & Standart Hata & $\beta$ & $t$ & $\mathrm{p}$ \\
\hline Sabit & $-5,564$ & 1,894 & - & $-2,937$ & 0,004 \\
\hline Ilgi & 0,964 & 0,129 & 0,362 & 7,444 & 0,000 \\
\hline Merak & 0,439 & 0,117 & 0,193 & 3,744 & 0,000 \\
\hline Tanınma & 0,062 & 0,141 & 0,022 & 0,438 & 0,661 \\
\hline Sosyal & $-0,326$ & 0,102 & $-0,160$ & $-3,193$ & 0,002 \\
\hline Rekabet & 0,018 & 0,120 & 0,008 & 0,154 & 0,878 \\
\hline Uyum & 0,679 & 0,159 & 0,216 & 4,281 & 0,000 \\
\hline Tutum & 0,035 & 0,016 & 0,102 & 2,201 & 0,028 \\
\hline$R=0,627$ & $R^{2}=0,393$ & & & & \\
\hline$F_{(7,374)}=34,531$ & $p=0,000$ & & & & \\
\hline
\end{tabular}

Tablo 6'ya göre, iligi, Merak, Tanınma, Sosyal, Rekabet, Uyum alt ölçek puanları ve Türkçe dersine yönelik tutum puanları, okuduğunu anlama testi başarı puanları ile orta düzeyde ve pozitif yönde bir ilişki vermektedir $\left(R=0,63 ; R^{2}=0,39 ; p<0,01\right)$. Bu üç değişken ile okuduğunu anlama başarı testi puanlarındaki değişkenliğin \%39'unu açıklanmaktadır. İçsel ve dışsal motivasyon puanları yerine alt ölçek puanları regresyona alındığında, açıklanan varyans oranı 0,33'ten 0,39'a yükselmiştir. Standartlaştırılmış Beta katsayılarına göre, okuduğunu anlama üzerindeki en etkili değişkenler sırasıyla illgi, Uyum, Merak, Sosyal, Tutum, Tanınma ve Rekabet değişkenleridir. Analiz sonucu hesaplanan regresyon katsayılarının önemlilikleri incelendiğinde ise Tanınma ve Rekabet dışındaki değişkenlerin okuduğunu anlama üzerinde manidar bir etkiye sahip olduğu görülmektedir $(p<0,05)$. Bu analiz bulgularına göre regresyon eşitliği aşağıdaki gibi oluşturulabilir:

Okuduğunu Anlama $=-5,564+(0,96 *$ ilgi $)+(0,44 *$ Merak $)+(0,06 *$ Tanınma $)+(-0,33 *$ Sosyal $)+$ $(0,02 *$ Rekabet $)+(0,68 *$ Uyum $)+(0,04 *$ Tutum $)$ 


\section{Tartışma ve Sonuç}

Bu araştırma, beşinci sınıf öğrencilerinin okuduğunu anlama becerileri ile okuma motivasyonu ve Türkçe dersine yönelik tutum arasındaki ilişkiyi belirlemek amacıyla gerçekleştirilmiştir. Araştırmanın amacı doğrultusunda elde edilen sonuçlar, kuramsal bilgiler ve benzer araştırma sonuçlarıyla kıyaslanarak tartışılmış, elde edilen bulgular ışığında araştırmacılara ve öğretmenlere yönelik öneriler geliştirilmiştir.

Okuma, öğrencilerin araştırma becerilerinin geliştirilmesinde önemli yer tutan bir öğrenme alanıdır (Fidan, 2020). "Dört temel dil becerisi içinde okuma; temel bilgi edinme vasıtası olması yönüyle bireylere hayat boyu sürecek bir öğrenme sürecinin kapılarını açmaktadır. Eğitim sürecinin neredeyse tamamında okuma sayesinde bilgiye ulaşılmakta ve öğretim basamakları düzenlenmektedir" (Balcı, 2013 , s.2). Bilgi alışverişinin yoğun olduğu günümüzde okuduğunu anlamanın önemi daha da artmıştır. Bu nedenle ilköğretim sürecinden itibaren öğrencilerin okuma becerileri geliştirilmelidir. Araştırmaya katılan beşinci sınıf öğrencilerinin okuduğunu anlama düzeylerinin orta düzeyde olduğu görülmektedir. Bu araştırmadan elde edilen sonuçlara göre beşinci sınıf öğrencilerinin okuduğunu anlama düzeylerinin yeterli düzeyde olmadıkları görülmektedir. Araştırmadan elde edilen bu sonuçlar alanyazındaki bazı araştırmaların bulgularıyla da benzerlik göstermektedir (Altunkaya, 2017; Batmaz ve Erdoğan, 2019; Erdem, 2016; Ergen ve Batmaz, 2019; Kuşdemir ve Katrancı, 2016; Özder, Konedralı ve Doğan, 2012).

Okuma becerisinin önemi, teknolojinin büyüyen etkisi ve hızlı değişimiyle son yıllarda önemli ölçüde artmıştır. Bireysel gelişim, akademik başarı, ekonomik katıım ve vatandaşık gibi alanlarda 20 yıl önce ihtiyaç duyulan okuma becerisi ile günümüzde ihtiyaç duyulan okuma becerisi nitelik ve içerik açısından farklıdır. PISA 2018 uygulamasında okuma becerileri; "kişinin hedeflerine ulaşmak, bilgi ve potansiyelini geliştirmek ve topluma katılmak amacıyla çeşitli şekillerde sunulan metinleri anlaması, kullanması, değerlendirmesi, ilişkilendirmesi ve metinler üzerine derinlemesine düşünmesi" (OECD, 2019) şeklinde tanımlanmaktadır. 2018 yılında yapılan PISA sınavında Türkiye'nin okuma becerisi performansları ele alındığında daha önceki yıllarda yapılan uygulamalara göre bir gelişme kaydedilmiştir. Ancak katılımcı ülkelerle birlikte ele alındığında sonuçların çok iyi olmadığı görülmektedir. Türkiye, PISA 2018'e katılan 79 ülke arasında okuma becerileri alanında 40. sırada, 37 OECD ülkesi arasında ise 31. sırada yer almaktadır (MEB, 2019a). Raporda belirtilen bu sonuçlar, mevcut araştırmanın bulguları ile birlikte değerlendirildiğinde, öğrencilerin okuduğunu anlama düzeylerinin istenilen düzeyde olmadığı söylenebilir. Türkben'e (2018) göre okuma becerisinin geliştirilmesi için okuma sürecinde strateji kullanımına ağırlık verilmelidir. Başarılı okuyucular okuma eylemini stratejik olarak gerçekleştirirler. Onlar dinamik bir süreç olan okumanın gereği olarak her gün okumaya ve okuma stratejilerini kullanmaya çalışırlar.

Araştırmaya katılan öğrencilerin okuma motivasyonlarının yüksek düzeyde olduğu görülmektedir. Araştırmanın bu bulgusu birçok çalışma ile paralellik göstermektedir (Bozkurt ve Memiş, 2013; illeri, 2011; Kurnaz ve Yıldız, 2015; Türkben, 2020; Ürün-Karahan, 2015; Ürün-Karahan ve Taşdan, 2016; Yıldız, 2010, 2013a, 2013b). Ürün-Karahan ve Taşdan (2016) 5. ve 6. sınıf öğrencilerinin okumaya karşı tutumlarını ve okuma motivasyonlarını ortaya koymak ve anlama düzeyi, okuduğunu anlama becerisi, kişisel eğilimden kaynaklanan okuma ve okuldan kaynaklanan okuma dereceleri ile ilişkilerini belirlemeye çalıştıkları çalışmalarında, öğrencilerin okumaya yönelik tutum ve motivasyonlarının yüksek olduğu tespit edilmiştir. Ancak Yıldız (2013b) tarafından yapılan bir çalışmada çıkan bir sonuç oldukça önemlidir. 3, 4 ve 5 . sınıf öğrencilerinin okumaya yönelik içsel ve dışsal motivasyonlarının incelendiği bu çalışmada sınıf düzeyi ilerledikçe öğrencilerin okuma motivasyonlarının azaldığı tespit edilmiştir. Bu durum öğrencilerin okuma motivasyonlarının artırılmasına yönelik çalışmaları gerekli kılmaktadır. Motivasyon kadar tutum da akademik başarı üzerinde etkilidir. İlgili alanyazın incelendiğinde öğrencilerin Türkçe dersine yönelik tutumlarının genelde olumlu olduğu görülmektedir (Bölükbaş, 2010; Erdem ve Gözüküçük, 2013; Zorbaz ve Habeş, 2015). Alanyazında yapılmış bu çalışmalardan elde edilen bulgular mevcut çalışmadan elde edilen bulgularla örtüşmektedir.

Araştırmaya katılan beşinci sınıf öğrencilerinin okuduğunu anlama, okuma motivasyonu ve Türkçe dersine yönelik tutum puanları cinsiyet değişkenine göre de incelenmiştir. Elde edilen bulgulara göre, öğrencilerin okuduğunu anlama testi puanları cinsiyete göre 0,01 hata düzeyinde manidar 
farklılık göstermekte ve bu farklıık kız öğrenciler lehinedir. Başka bir ifade ile kız öğrencilerin okuduğunu anlama düzeyleri, erkek öğrencilere kıyasla istatiksel olarak anlamlı şekilde daha yüksektir. Alanyazında yapılmış başka çalışmalarda da benzer sonuçlar elde edilmiştir (Altunkaya, 2017; Balcı, 2009; Güngör ve Açıkgöz, 2005; Sallabaş, 2008; Temizyürek, 2008). Yıldız (2010), Anılan (2004), Kuşdemir ve Katrancı (2016) ve Wang ve Guthire (2004) tarafından gerçekleştirilen araştırmalarda da kız ve erkek öğrencilerin okuduğunu anlama puanları arasında cinsiyete göre anlamlı farklıık göstermektedir. Mevcut araştırma bulgularına göre kız öğrencilerin içsel ve dışsal motivasyonlarının erkek öğrencilere göre daha yüksek olduğu belirlenmiştir. Yıldız (2010) ve Sani vd. (2011) tarafından yapılan araştırma sonuçlarına göre kızların okumaya yönelik motivasyonlarının erkeklerden daha yüksek olduğu tespit edilmiştir. Katrancı (2015) tarafından yapılan araştırmada da kız öğrencilerin kitap okuma motivasyonlarının erkek öğrencilere göre daha yüksek olduğu belirlenmiştir. Yıldız (2013) ve Sancı'nın (2002) yapmış oldukları araştırmalarda ise içsel motivasyon bakımından kızlar ve erkekler arasında anlamlı farklıık bulunmamakla birlikte dışsal motivasyonda kızların erkeklerden daha yüksek puana sahip oldukları saptanmıştır. Araştırma bulgularına göre kız öğrencilerin Türkçe dersine yönelik tutum puanları erkek öğrencilere göre yüksek düzeydedir. Elde edilen bu sonuç alanyazındaki diğer araştırma sonuçlarıyla da desteklenmektedir (Bölükbaş, 2010; Deniz ve Tuna, 2006; Erdem ve Gözüküçük, 2013; Gür, Dilci, Şener ve Yıldırım, 2013; Kaya, Arslantaş ve Şimşek, 2009; Okur ve Özsoy, 2013; Zorbaz ve Habeş, 2015).

Araştırma kapsamında beşinci sınıf öğrencilerinin okuma motivasyonları, Türkçe dersine yönelik tutumları ve okuduğunu anlama düzeyleri arasındaki ilişki de belirlenmeye çalışımıştır. Öğrencilerin okuduğunu anlama düzeylerini ölçen başarı testi puanları ile içsel motivasyon puanları arasında pozitif yönde ve orta düzeyde; öğrencilerin okuduğunu anlama düzeylerini ölçen başarı testi puanları ile dışsal motivasyon puanları arasında orta altı düzeyde ve pozitif yönde; öğrencilerin okuduğunu anlama düzeylerini ölçen başarı testi puanları ile motivasyon puanları arasında orta düzeyde ve pozitif yönde; öğrencilerin okuduğunu anlama düzeylerini ölçen başarı testi puanları ile Türkçe dersine yönelik tutum puanları arasında orta altı düzeyde pozitif yönde bir ilişki vardır. Öğrencilerin içsel motivasyon puanları ile dışsal motivasyon puanları arasında orta düzeyde ve pozitif yönde; öğrencilerin içsel motivasyon puanları ile motivasyon puanları arasında yüksek düzeyde ve pozitif yönde; öğrencilerin içsel motivasyon puanları ile Türkçe dersine yönelik tutum puanları arasında orta düzeyde ve pozitif yönde bir ilişki olduğu belirlenmiştir. Dışsal motivasyon ile motivasyon arasında oldukça yüksek düzeyde ve pozitif yönde; dışsal motivasyon ile tutum puanları arasında orta düzeyde ve pozitif yönde ve son olarak motivasyon puanları ile tutum puanları arasında da orta düzeyde ve pozitif yönde bir ilişki olduğu görülmektedir.

Araştırma bulgularına göre içsel motivasyon, dışsal motivasyon ve Türkçe dersine yönelik tutum puanları, okuduğunu anlama testi başarı puanları ile orta düzeyde ve pozitif bir ilişki vermektedir. Bu üç değişken ile okuduğunu anlama başarı testi puanlarındaki değişkenliğin \% 33'ünü açıklamaktadır. Elde edilen bulgulara göre okuduğunu anlama üzerindeki en etkili değişken içsel motivasyondur. Onu takiben sırasıyla Türkçe dersine yönelik tutum ve dışsal motivasyon gelmektedir. Analiz sonucu hesaplanan regresyon katsayılarının önemlilikleri incelendiğinde ise içsel motivasyon ve tutumun okuduğunu anlama üzerinde manidar bir etkiye sahip olduğu görülmektedir $(p<0,05)$. Bununla birlikte dışsal motivasyon okuduğunu anlama üzerinde anlamlı bir etkiye sahip değildir. İçsel motivasyonun okuduğunu anlama üzerinde anlamlı ve pozitif bir etkiye sahip olduğuna yönelik araştırmalar da mevcuttur (Retelsdorf vd., 2011; Scafferner vd., 2013; Stutz vd., 2016; Yamaç ve Çeliktürk-Sezgin, 2018; Wang ve Guthrie, 2004; Yıldız ve Akyol, 2011; Yıldız, 2013a). Bazı çalışmalarda ise dışsal motivasyonun okuduğunu anlama üzerinde herhangi bir etkiye sahip olmadığını göstermektedir (Law, 2009; Scafferner vd., 2013; Stutz vd., 2016; Yamaç ve Çeliktürk-Sezgin, 2018; Wang ve Guthrie, 2004). Yıldız (2010) tarafından yapılan araştırma sonuçlarına göre, içsel motivasyonun okuduğunu anlamaya olumlu yönde etkisinin olduğu belirlenmiştir. Bu durum içsel motivasyonun öğrencilerin okuduğunu anlamak için ihtiyaçları olan bilişsel ve duyuşsal becerileri geliştirdiğini göstermektedir. Dışsal motivasyonun okuduğunu anlamayı olumsuz yönde etkilediği ancak dışsal motivasyonun "rekabet" boyutunun okuduğunu anlamaya olumlu yönde etkisinin olduğu belirlenmiştir. Yıldız (2013a) tarafından yapılan bir başka araştırmada da okuma motivasyonu, akıcı 
okuma ve okuduğunu anlamanın beşinci sınıf öğrencilerinin akademik başarılarındaki değişimin \% 61'ini açıkladığını göstermiştir. Yıldız (2013b) okulda başarılı olmak için içsel ve dışsal motivasyon kaynaklarının birlikte kullanılması gerektiğini vurgulamaktadır. Erdem ve Gözüküçük (2013) tarafından yapılan araştırmada öğrencilerin Türkçe dersine yönelik motivasyonu ile tutumu arasında pozitif ve anlamlı bir ilişki tespit edilmiştir. Olumlu tutum, öğrencilerin akademik başarısını da etkileyecektir. Öğrencilerin bir dersle ilgili duyuşsal özelliklerinin en önemli göstergelerinden biri tutumlardır (Kazazoğlu, 2013).

Bireylerin eleştirel ve yaratıcı okumanın gerektirdiği donanıma sahip olmalarında okuma öğretiminde kullanılan strateji, yöntem ve tekniklerin büyük bir etkisi vardır (Türkben, 2017). Öğrenme ortamlarında uygulanacak iş birlikli öğrenme çalışmaları ile öğretmen-öğrenci etkileşiminin yanında öğrenci-öğrenci etkileşimi de sağlanacak ve bu sayede öğrencilerin belirlenen hedeflere ulaşması kolaylaşacaktır (Bayburtlu, 2015). Okuma, doğuştan getirilen bir yetenek değil, öğretim ortamlarında kazanılabilen bir beceri alanıdır. Okuma ve okunandan anlam kurma becerilerini kazandırmak için öğrenme ortamlarında öğrencilerin bu donanımları kazanmalarını sağlamamız gerekir. Eğitim sistemimizde istenilen başarıyı elde etmek için bilişsel ve devinişsel alandaki beceriler kadar duyuşsal davranış ve becerilerin de kazandırılmasına da öncelik verilmelidir. Öğrencilerin dersi sevmeleri ile başarıları arasında yakın bir ilişki bulunmaktadır. Bu nedenle öğretmenlerin eğitim-öğretim ortamını düzenlerken ve öğrencilerle ilişkilerini belirlerken öğrencilerin duyuşsal özelliklerini dikkate almaları gerekmektedir. Bu çalışma beşinci sınıf öğrencileri ve çalışma grubundaki öğrencilerle sınırlıdır. Gelecekte, örneklem grubu daha geniş tutularak, 5.sınıf öğrencileriyle birlikte 6, 7 ve 8 . sınıf öğrencilerini de kapsayan başka çalışmalar da gerçekleştirilebilir. Okuduğunu anlama sürecini etkileyen değiş̧enlerin etkisini daha iyi anlamak için öğrencilerle görüşmeler yapılabilir. Nitel araştırmalarla konu derinlemesine daha iyi incelenebilir.

\section{Araştırma ve Yayın Etiği}

Bu çalışmada "Yükseköğretim Kurumları Bilimsel Araştırma ve Yayın Etiği Yönergesi" kapsamında uyulması belirtilen tüm kurallara uyulmuştur. Yönergenin ikinci bölümü olan "Bilimsel Araştırma ve Yayın Etiğine Aykırı Eylemler" başlığı altında belirtilen eylemlerden hiçbiri gerçekleştirilmemiştir.

\section{Etik Kurul İzni}

Yukarıda geçerlik ve güvenirliklerine ilişkin bilgiler sunulan üç ölçeğin bu araştırmada kullanılması için ölçek sahibi araştırmacılardan, MEB'den ve Etik Kuruldan gerekli izinler alınmıştır. Veriler 2019-2020 güz döneminde Aksaray il merkezindeki okullardan toplanmıştır. Araştırmanın bağımsız değişkenlerine ilişkin demografik bilgiler ise araştırmacılar tarafından oluşturulan bir anket formu yardımıyla elde edilmiştir. Uygulamalar, iki ders saati içerisinde, öğrencilerin öğretmenleri yardımıyla araştırmacılar tarafından yapılmıştır.

Kurul adı = Aksaray Üniversitesi İnsan Araştırmaları Etik Kurulu

Karar tarihi $=22.06 .2020$

Belge sayı numarası 06

\section{Yazarların Katkı Oranı}

Makalenin hazırlanmasında 1. yazar \%60, 2. yazar \%40 oranında katkı sağlamıştır.

\section{Çıkar Çatışması}

Bu araştırmada çıkar çatışması teşkil edebilecek herhangi bir durum ya da ilişki yoktur.

\section{Kaynaklar}

Akyol, H. (2014). Türkçe öğretim yöntemleri. (7. Baskı). Ankara: Pegem Akademi Yayıncılık.

Altunkaya, H. (2017). İlkokul beşinci sınıf öğrencilerinin okuma kaygıları ile okuduğunu anlama becerileri arasındaki ilişki. International Journal of Language Academy, 5(3), 106-121. 
Anılan, H. (2004). Bazı değişkenler açısından Türkçe dersinde okuduğunu anlama. Afyon Kocatepe Üniversitesi Sosyal Bilimler Dergisi, 6, 90-102.

Ateş, M. (2008). Ilköğretim ikinci kademe öğrencilerinin okuduğunu anlama düzeyleri ile Türkçe dersine karşı tutumları ve akademik başarıları arasındaki ilişki (Yayımlanmamış doktora tezi). Selçuk Üniversitesi Sosyal Bilimler Enstitüsü, Konya.

Baker, L., \& Wigfield, A. (1999). Dimensions of children's motivation for reading and their relations to reading activity and reading achievement. Reading Research Quarterly, 34(4), 452-477. DOI:10.1598/RRQ.34.4.4

Balcı, A. (2009). Illköğretim 8. sınıf öğrencilerinin okuma alışkanlık ve ilgileri üzerine bir araştırma (Yayımlanmamış doktora tezi). Gazi Üniversitesi Eğitim Bilimleri Enstitüsü, Ankara.

Balcı, A. (2013). Okuma ve anlama. Ankara: Pegem Akademi.

Batmaz, O. ve Erdoğan, Ö. (2019). İlkokul 4.sınıf öğrencilerinin okuma motivasyonları ile okuduğunu anlama becerileri arasındaki ilişki ve bu konuya yönelik öğretmen görüşleri. Elektronik Sosyal Bilimler Dergisi, 18(71), 1429-1449.

Bayburtlu, Y. S. (2015). İ̧̧birliğine dayalı öğrenme yaklaşımının 6.sınıf Türkçe dersi kazanımlarına etkisi. Turkish Studies, 10(11), 235-274.

Becker, M., McElvany, N., \& Kortenbruck, M. (2010). Intrinsic and extrinsic reading motivation as predictors of reading literacy: A longitudinal study. Journal of Educational Psychology, 102(4), 773785. DOI:10.1037/a0020084

Brown, H. D. (2001). Teaching by principles: An interactive approach to language pedagogy (2nd ed.). New York, NY: Addison Wesley Longman.

Bozkurt, M. ve Memiş, A. (2013). Beşinci sınıf öğrencilerinin üstbilişsel okuduğunu anlama farkındalığı ve okuma motivasyonları ile okuma düzeyleri arasındaki ilişki. Kırşehir Eğitim Fakültesi Dergisi, 14(3), 147-160.

Bölükbaş, F. (2010). İlköğretim öğrencilerinin Türkçe dersine yönelik tutumlarının başarı-cinsiyetailenin eğitim düzeyi bağlamında değerlendirilmesi. Turkish Studies, 5(3), 905-918.

Büyüköztürk, Ş. (2009). Sosyal bilimler için veri analizi el kitabı. Ankara: Pegem Akademi.

Büyüköztürk, Ş. (2008). Sosyal bilimler için istatistik. Ankara: Pegem Akademi.

Calp, M. ve Calp, Ş. (2016). Özel öğretim alanı olarak Türkçe öğretimi. Ankara: Nobel Akademik Yayıncilık.

Deci, E. L., \& Ryan, R. M. (1985). Intrinsic motivation and self-determination in human behavior. New York: Plenum

Demirel, Ö. (1999). illöğretim okullarında Türkçe öğretimi. İstanbul: MEB.

Deniz, S. ve Tuna, S. (2006). İlköğretim öğrencilerinin Türkçe dersine yönelik tutumları: Köyceğiz Örneklemi. Milli Ĕ̆itim Dergisi, 34(170), 339-350.

Durkin, D. (1993). Teaching them to read. Boston: Allyn \& Bacon.

Erdem, A.R. ve Gözüküçük, M. (2013). Illköğretim 3. 4. ve 5. sınıf öğrencilerinin Türkçe dersine yönelik motivasyonları ve tutumları arasındaki ilişki. Pegem Eğitim ve Öğretim Dergisi (PEGEGOG), 3(2), 13-24.

Ergen, Y. ve Batmaz, O. (2019). İlkokul 4.sınıf öğrencilerinin okuduğunu anlama stratejilerini kullanma düzeyleri ile okuduğunu anlama başarıları arasındaki ilişki. Mehmet Akif Ersoy Eğitim Fakültesi Dergisi, 49, 130-147.

Fidan, M. ve Eren, A. (2017). Relationships between the profiles of middle school students' attitudes towards Turkish course and motivations for education, $H$. U. Journal of Education, 32(2), 480493. DOI: $10.16986 /$ HUJE.2017024892

Fidan, M. (2020). Türkçe ders kitaplarındaki araştırma yönergelerinin niteliksel yönlerinin karşılaştırmalı analizi. Turkish Studies, 15(7), 2923-2941. DOI: 10.7827/TurkishStudies.44822

Francis, L. J., \& Greer, J. E. (1999). Attitude toward science among secondary pupils in northern ireland: relationship with sex, age and religion. Research in Science \& Technological Education, 17, 6575. 
Guthrie, J. T., Hoa, A. L. W., Wigfield, A., Tonks, S. M., Humenick, N. M., \& Littles, E. (2007). Reading motivation and reading comprehension growth in the later elementary years. Contemporary Educational Psychology, 32(3), 282-313. DOI: 10.1016/j.cedpsych.2006.05.004

Güngör, A. ve Açıkgöz, K. (2005). İşbirlikli öğrenme ve geleneksel öğretimin okuduğunu anlama üzerinde etkileri ve cinsiyet ile ilişkileri. Kuram ve Uygulamada Eğitim Yönetimi, 43, 354-378.

Gür, T., Dilci, T., Şener, H. ve Yıldırım, T. (2013). Effects of some variables on 4th year students' attitudes towards Turkish course. Cumhuriyet International Journal of Education. 2(1), 118-134.

Harris, A. J. ve Sipay, E. R. (1990). How to increase reading ability: A guide to developmental \& remedial methods. New York: Longman.

Just, M. A., \& Carpenter, P. A. (1980). A theory of reading: From eye fixations to comprehension. Psychological review, 87(4), 329-354.

Karasakaloğlu, N. ve Saracaloğlu A. S. (2009). Sınıf öğretmeni adaylarının Türkçe derslerine yönelik tutumları ile başarıları arasındaki ilişki. Yüzüncü Yıl Üniversitesi Eğitim Fakültesi Dergisi, 5(1), 343362.

Kaya, A. i., Arslantaş, H. i. ve Şimşek, N. (2009). İlköğretim öğrencilerinin Türkçe dersine karşı tutumlarının değerlendirilmesi. Elektronik Sosyal Bilimler Dergisi, 30(30), 376-387.

Kaya, T. (2011). Illköğretim ikinci kademe Türkçe dersi proje görevi başarı puanları ile akademik başarı ve derse yönelik tutum arasındaki ilişkinin değerlendirilmesi (Yayımlanmamış yüksek lisans tezi). Karadeniz Teknik Üniversitesi Eğitim Bilimleri Enstitüsü, Trabzon.

Kağıtçıbaşı, Ç. (1999). Yeni insan ve insanlar (10. basım). İstanbul: Evrim Yayınevi.

Karasar, N. (2013). Bilimsel araştırma yöntemi. Ankara: Nobel Yayıncılık.

Katrancı, M. (2015). İlkokul dördüncü sınıf öğrencilerinin kitap okuma motivasyonlarının incelenmesi. Ana Dili Eğitimi Dergisi, 3(2), 49-62.

Katrancı, M. ve Kuşdemir, Y. (2016). Okumada kaygı ve anlama: Ana Fikri Bulamıyorum Öğretmenim!, Eğitim ve Bilim, 41(183), 251-266.

Kazazoğlu, S. (2013). Türkçe ve İngilizce derslerine yönelik tutumun akademik başarıya etkisi. Eğitim ve Bilim, 38(170), 294-307.

Kurnaz, H. ve Yıldız, N. (2015). Ortaokul öğrencilerinin okuma motivasyonlarının çeşitli değişkenlere göre değerlendirilmesi. Türkiye Sosyal Araştırmalar Dergisi, 19(3), 53- 70.

Law, Y. K. (2009). The role of attribution beliefs, motivation and strategy use in Chinese fifth-graders' reading comprehension. Educational Research, 51(1), 77-95. DOI: 10.1080/00131880802704764

MEB. (2019). Türkçe dersi (1-8. sınıflar) öğretim programı. Ankara: Devlet Kitapları Müdürlüğü.

MEB. (2019a). PISA 2018 Türkiye ön raporu. http://pisa.meb.gov.tr/wpcontent/uploads/2020/01/PISA_2018_Turkiye_On_Raporu.pdf Erişim Tarihi: 11.06.2020

National Reading Panel (2000). Report of the national reading panel. Teaching children to read: An evidence-based assessment of the scientific research literature on reading and its implications for reading instruction. Washington, DC: National Institute of Child Health and Human Development.

OECD (2019). PISA 2018 results volume I: What students know and can do. Paris: OECD Publishing.

Okur, A. ve Özsoy, Y. (2013). Üstün zekâlı öğrencilerin Türkçe dersine yönelik tutumlarının incelenmesi: Bartın Bilsem Örneği. Eğitimde Kuram ve Uygulama, 9(3), 254-264.

Özder, H., Konedralı, G. ve Doğan, H. (2012). Illkokul beşinci sınıf öğrencilerinin okuduğunu anlama becerilerinin değerlendirilmesi. Uluslararası Eğitim Programları ve Öğretim Çalışmaları Dergisi, 2(4), 13-26.

Öztürk, P. (2010). Illköğretim II. kademe Türkçe dersi performans görevi başarı puanları ile akademik başarı ve derse yönelik tutum arasındaki ilişkinin değerlendirilmesi (Yayımlanmamış yüksek lisans tezi). Karadeniz Teknik Üniversitesi Eğitim Bilimleri Enstitüsü, Trabzon.

Retelsdorf, J., Köller, O., \& Möller, J. (2011). On the effects of motivation on reading performance growth in secondary school. Learning and Instruction, 21(4), 550-559. DOI: 10.1016/j.learninstruc.2010.11.001

Sallabaş, M. E. (2008). İlköğretim 8.sınıf öğrencilerinin okumaya yönelik tutumları ve okuduğunu anlama becerileri arasındaki ilişki. Inönü Eğitim Fakültesi Dergisi, 9(16), 141-155. 
Sancı, D. (2002). Illköğretim 6. sınıf öğrencilerinin toplumsal, ekonomik ve kültürel durumlarının okuma motivasyonuna etkisi (Yayımlanmamış yüksek lisans tezi). Atatürk Üniversitesi Sosyal Bilimler Enstitüsü, Erzurum.

Sani, B. B., Chik M.N.B.W., Nik Y.B.A., \& Raslee N.A.B.R. (2011). The reading motivation and reading strategies used by undergraduates in University Teknologi MARA Dungun, Terengganu. Journal of Language Teaching and Research, 2, 32-39.

Schaffner, E., Schiefele, U., \& Ulferts, H. (2013). Reading amount as a mediator of the effects of intrinsic and extrinsic reading motivation on reading comprehension. Reading Research Quarterly, 48(4), 369385. DOI:10.1002/rrq.52

Schallert, D.L., \& Reed,J .H. (1997). The pull of the text and the process of involvement in reading. In J.T. Guthrie \& A. Wigfield (Eds.), Reading engagement: Motivating readers through integrated instruction (pp. 68-85). Newark, D E: International Reading Association.

Stutz, F., Schaffner, E., \& Schiefele, U. (2016). Relations among reading motivation, reading amount, and reading comprehension in the early elementary grades. Learning and Individual Differences, 45, 101113. DOI: 10.1016/j.lindif.2015.11.022

Sweet, A.P., \& Snow, C. (2002). Reconceptualizing reading comprehension. In L.B. Gambrell, C.C. Block, M. Pressley (Edt.) Improving Comprehension Instruction (1st Edition) (pp. 17-53) San Francisco: Jossey-Bass

Temizyürek, F. (2008). The impact of different types of texts on Turkish language reading comprehension at primary school grade eight students. Eurasian Journal of Educational Research, 30, 141-152

Ülper, H. (2010). Okuma ve anlamlandırma becerilerinin kazandırılması. Ankara: Nobel Yayınları.

Ürün-Karahan, B. (2015). Öğretmen adaylarının okumaya yönelik motivasyonlarının çeşitli değişkenler açısından incelenmesi (Kafkasya Üniversitesi Örneği). Turkish Studies, 10(11), 1569-1586.

Ürün-Karahan, B. ve Taşdan, M. (2016). 5. ve 6. sınıf öğrencilerinin okumaya karşı tutum ve motivasyonlarının okuduğunu anlama becerileri ile ilişkisi. Uluslararası Türkçe Edebiyat Kültür Eğitim Dergisi, 5(2), 949-969.

Taboada, A., Tonks, S. M., Wigfield, A., \& Guthrie, J. T. (2009). Effects of motivational and cognitive variables on reading comprehension. Reading and Writing, 22(1), 85-106. DOI: 10.1007/s111450089133-y

Tavşancıl, E. (2002). Tutumların ölçülmesi ve SPSS ile veri analizi. Ankara: Nobel Yayın Dağııım.

Topçuoğlu Ünal, F. ve Köse, M. (2014). Türkçe dersine yönelik tutum ölçeği geliştirilmesi: Bir geçerlilik ve güvenirlik çalışması. Bartın Üniversitesi Eğitim Fakültesi Dergisi, 3(2), 233-249.

Türkben, T. (2017). Etkileşimsel okuma modelini temel alan Türkçe öğretiminin öğrencilerin bilişsel ve duyuşsal öğrenme becerileri üzerine etkisi (Yayımlanmamış doktora tezi). Gazi Üniversitesi Eğitim Bilimleri Enstitüsü, Ankara.

Türkben, T. (2018). The effect of Turkish teaching based on interactive reading model on cognitive awareness skills of students. International Journal of Language Academy, 6(1), 120-147 DOI: 10.18033/ijla.3868

Türkben, T. (2019). The effect of self-regulation based strategic reading education on comprehension, motivation, and self-regulation skills. International Journal of Progressive Education, 15(4), 2746. DOI: 10.29329/ijpe.2019.203.3

Türkben, T. (2020). Ortaokul öğrencilerinin okuma kaygıları, motivasyon düzeyleri ve okuduğunu anlama becerileri arasındaki ilişkiler. Dil Eğitimi ve Araştırmaları Dergisi, 6(2), 657-677. DOI: 10.31464/jlere.770661

Vansteenkiste, M., Lens, W., \& Deci, E. L. (2006). Intrinsic versus extrinsic goal contents in self determination theory: Another look at the quality of academic motivation. Educational Psychologist, 41, 19-31.

Wang, J. H., \& Guthrie, J. T. (2004). Modeling the effects of intrinsic motivation, extrinsic motivation, amount of reading, and past reading achievement on text comprehension between U.S. and Chinese students. Reading Research Quarterly, 39(2), 162-186. 
Wigfield, A., Guthire, J. T., Tonks, S., \& Prencevich, K. C. (2004). Children's motivation for reading domain specificity and instructional influences. The Journal of Educational Research, 97, 299309.

Yamaç, A. ve Çeliktürk Sezgin, Z. (2018). İlkokul dördüncü sınıf öğrencilerinin okuma kaygıları, akıcılıkları, motivasyonları ve okuduğunu anlamaları arasındaki ilişkiler. Eğitim ve Bilim, 43(194), 225-243.

Yıldız, M. (2010). ilköğretim 5. sınıf öğrencilerinin okuduğunu anlama, okuma motivasyonu ve okuma alışkanlıkları arasındaki ilişki (Yayımlanmamış doktora tezi). Gazi Üniversitesi Eğitim Bilimleri Enstitüsü, Ankara.

Yıldız, M. ve Akyol, H. (2011). İlköğretim 5. sınıf öğrencilerinin okuduğunu anlama, okuma motivasyonu ve okuma alışkanlıkları arasındaki ilişki. Gazi Üniversitesi Gazi Eğitim Fakültesi Dergisi, 31(3), 793815.

Yıldız, M. (2013a). Okuma motivasyonu, akıcı okuma ve okuduğunu anlamanın beşinci sınıf öğrencilerinin akademik başarılarındaki rolü. Turkish Studies, 8(4), 1461-1478.

Yıldız, M. (2013b). Ilköğretim 3, 4 ve 5. sınıf öğrencilerinin okuma motivasyonlarının incelenmesi. Eğitim ve Bilim, 38(168), 260-271.

Yıldız, M. ve Aktaş, N. (2015). Okuma motivasyonu ve okumaya adanmışlık ölçeği: Türkçeye uyarlama çalışması. International Journal of Human Sciences, 12(2), 1349-1365. DOI:10.14687/ijhs.v12i2.3379

Zorbaz, K. Z. ve Habeş (2015). Ortaokul öğrencilerinin Türkçe dersine yönelik tutumlarının çeşitli değişkenler açısından incelenmesi. Kastamonu Eğitim Dergisi, 23(4), 1737-1756.

\section{Extended Abstract}

\section{Introduction}

One of the most basic and critical language skills individuals can use in their lifelong learning processes is reading. For this reason, the foundations of reading education must be established firmly in the primary education process. Many factors are effective in reading comprehension, one of which is motivation. Motivation has an impact on the learning preferences and academic success of students. Motivation is an effect, which makes students have the desire to learn, understand, and study. Turkish courses are made use of in helping students acquire and improve their basic language skills and ensure their cognitive, affective, and social development. The attitude towards a course has an important function in increasing learning as one of the central affective variables. There are studies in the literature conducted on reading comprehension, reading motivation, and attitudes towards Turkish courses. However, it was found that there are no adequate studies that investigate the relations between reading comprehension, motivation, and attitudes towards Turkish courses. The purpose of the present study was to examine the relations between these variables.

\section{Method}

The present study used the correlational study design to examine the relations between the reading comprehension, reading motivation and attitudes towards Turkish courses of fifth-grade students. The Study Group consisted of 385 fifth-grade students who were studying in Aksaray city center in the fall semester of 2019-2020 Academic Year. The participants were determined by using the Simple Random Sampling Method. It was found that only one student left the gender information in the dataset blank; therefore, the dataset of this student was excluded from analyses. Statistical analyzes were conducted over the data of 384 students. A total of $52.4 \%$ of the students who were included in the study were male, and $47.3 \%$ of them were female. The Reading Motivation Scale, Reading Comprehension Test, and Attitude Scale towards Turkish Courses were used as the data collection tools in the present study.

\section{Result and Discussion}

According to the results obtained in this study, it was found that the level of reading comprehension of fifth-grade students was not at an adequate level. These results obtained from the 
study are similar to the findings of some previous studies in the literature (Altunkaya, 2017; Batmaz \& Erdoğan, 2019; Erdem, 2016; Ergen \& Batmaz, 2019; Kuşdemir \& Katrancı, 2016; Özder, Konedralı \& Doğan, 2012).

It was also found that the reading motivation of the students who participated in the study was at a high level. This finding of the present study was parallel to that of many previous studies (Bozkurt \& Memiş, 2013; İleri, 2011; Kurnaz and Yıldız, 2015; Türkben, 2020; Ürün-Karahan, 2015; Ürün-Karahan and Taşdan, 2016; Yıldız, 2010, 2013a, 2013b). Ürün-Karahan and Taşdan (2016) conducted a study to uncover the attitudes towards reading and reading motivations of $5^{\text {th }}$ and $6^{\text {th }}$ Grade students and to determine the relations between level of comprehension, reading comprehension skills, reading based on personal tendency and school, and found that the attitudes and motivations of the students were high. However, the results of a study conducted by Yıldız (2013b) are very important in this respect. In this study, which examined the internal and external motivations of $3^{\text {rd }}, 4^{\text {th }}$ and $5^{\text {th }}$ Grade students for reading, it was reported that as the grade increased, the reading motivation of students decreased. This requires that studies aimed to enhance the reading motivation of students are increased. Attitude has an effect on academic achievement as well as motivation. When the related literature was reviewed, it was found that the attitudes of students towards Turkish courses are reported to be generally positive (Bölükbaş, 2010; Erdem \& Gözüküçük, 2013; Zorbaz \& Habeş, 2015). The findings obtained in these studies conducted in the literature overlap with the findings obtained in the present study.

The scores of the fifth-grade students in reading comprehension, reading motivation and attitude towards the Turkish course were also analyzed according to the gender variable. According to the findings, the Reading Comprehension Achievement Test scores of the students differed at significant levels at the error level of 0.01 according to gender, and this difference was in favor of the female students. In other words, the reading comprehension levels of female students were higher at statistically significant levels than those of male students. According to the study findings, it was also found that the internal and external motivation and attitude scores towards the Turkish course of the female students were also higher than those of the male students.

The relationship between the reading motivation, attitudes towards Turkish courses, and reading comprehension levels of fifth-grade students was determined in the scope of the present study. A positive and moderate relation was detected between the achievement test scores that measure the reading comprehension levels of the students and the internal motivation scores, a positive and moderate relation was detected between the achievement test scores that measure the reading comprehension levels of the students and the external motivation scores, a positive and moderate relation was detected between the achievement test scores that measure the reading comprehension of students and their motivation scores, a positive and below-moderate relation was detected between the achievement test scores that measure the reading comprehension level of students and the attitude scores towards Turkish course. A positive and moderate relation was detected between the internal motivation scores of the students and their external motivation scores, a positive and high-level relation was detected between the internal motivation scores of the students and their motivation scores, a positive and high-level relation was detected between the internal motivation scores of the students and their attitude scores towards the Turkish course. A positive and very high-level relation was detected between the external motivation and motivation, a positive and high-level relation was detected between the external motivation and attitude scores, and finally, a moderate and positive relationship was detected between motivation scores and attitude scores.

According to the findings of the study, internal motivation, external motivation, and attitude scores towards Turkish courses have moderate and positive relations with the Reading Comprehension Achievement Test scores. These three variables explain 33\% of the variability in Reading Comprehension Achievement Test scores. According to the findings, the most effective variable on reading comprehension is internal motivation. Following this, there are the attitudes towards Turkish courses and external motivation, respectively. When the significance of the regression coefficients that were calculated in the analyses was examined, it was found that internal motivation and attitudes have 
Tuncay TÜRKBEN, Ceylan GÜNDEĞER

significant effects on reading comprehension $(p<0.05)$. However, external motivation did not have significant effects on reading comprehension. 